Arctoa (2004) 13: 203-209

\title{
IWATSUKIA JISHIBAE (STEPH.) KITAGAWA (CEPHALOZIACEAE, HEPATICAE) IN RUSSIA
}

\section{IWATSUKIA JISHIBAE (STEPH.) KITAGAWA (CEPHALOZIACEAE, НЕРАТІСАЕ) В РОССИИ}

\author{
N. A. Konstantinova ${ }^{1}$ \\ Н. А. КонСТАнтиновА ${ }^{1}$
}

\begin{abstract}
The worldwide rare Iwatsukia jishibae (Steph.) Kitagawa was found to be relatively common in Khamar-Daban Range near the south end of Lake Baikal (South Siberia). A detailed description of this species, as well as differences from allied species are given, and there is a key to genera of Cephaloziaceae in Russia. Mainly a tropical-subtropical species, $I$. jishibae has a disjunct distribution in Central America, West and East Africa, Indian Ocean islands, Papua-New Guinea, Nepal, Japan, Korea and South Siberia. This species occurs exclusively on rotting wood. Iwatsukia exigua is believed to be conspecific with I. jishibae.

Резюме

Редкий в мире вид Iwatsukia jishibae (Steph.) Kitagawa обнаружен в нескольких точках в долинах рек на северном макросклоне хребта Хамар-Дабан (Южная Сибирь). Приводится детальное описание вида, отличия его от близких таксонов, ключ для определения видов семейства Cephaloziaceae в России. Обсуждается экология и распространение вида.
\end{abstract}

\section{INTRODUCTION}

While investigating the hepatic flora of the Baikalskiy Strict Nature Reserve in the KhamarDaban Range near the south end of Lake Baikal, South Siberia, Iratsukia jishibae (Steph.) Kitagawa was found in some valleys on the northern slopes of these mountains. This species was collected, with copious sporophytes, in many sites (Fig.1). Previously, this puzzling species was known from disjunct localities in Central America, Africa, and other parts of Asia (Fig.1). In Russia, the first records of $I$. jishibae were from the Altai Mountains (Vana, 1991-1992). Then it was discovered in the Sayan Mountains (Konstantinova \& Vasiljev, 1994) and later the species was collected in Udokan Mountains (southern East Siberia) by V.A.Bakalin (Bakalin, 2004). The specimens from Altai, Sayan and Udokan Mountains are quite small and sparse. Thus, finding numerous populations in the Khamar-Daban Range is surprising. Apparently, this species is not rare in these mountains. This rich material from South Siberia makes it possible to provide a detailed description of this poorly known species.

\section{DESCRIPTION}

Iwatsukia jishibae (Steph.) Kitagawa, Acta Phytotax. Geobot. 21. (3-4): 114. 1965; Grolle, J. Hattori Bot. Lab., 28: 103. 1965. - Cephalozia jishibae Steph., Spec. Hep. 6:437. 1952. - Cephaloziella jishibae Hattori, J. Hattori Bot. Lab., 7: 43. 1952. - Cephaloziella flagellaris Hattori, J. Hattori Bot. Lab., 3: 1. 1948. - Sphenolobus flagellaris Grolle, Misc. Bryol. et Lichen. 3: 17. 1963. Fig. 1.

Plants light to pale green, leafy shoots $0.4-0.6$ $\mathrm{mm}$ wideand (1-)2-10 $\mathrm{mm}$ long, the tip of shoots often with flagellae that deeply penetrate substrate and give rise to sterile, male or female shoots. Flagellae ca. $0.2 \mathrm{~mm}$ wide and $10-12 \mathrm{~mm}$ long (sometimes even more but it is very difficult to measure them because flagella are easy to destroy when being prepared). Branching ventral-intercalary, irregular, stolons not rare. Stem ca. $80-95 \mu \mathrm{m}$ wide, 5-6 cells high, with 14 rows of cortical cells and 5-8 rows of medullary cells (Fig. 1-3), that are much longer than the cortical. In cross-section, cortical cells not differentiated from the medullary ones or partly slightly larger, isodiametric or elon-

1 - Россия 184256, Мурманская область, Кировск-6, Полярно-альпийский ботанический сад-институт Кольского НЦ РАН - Polar-Alpine Botanical Garden-Institute of Kola Sci. Center of RAS, Kirovsk-6, Murmansk Province 184256 Russia; e-mail: nadya_k@aprec.ru 
gate $12-17 \times 14-15 \mu \mathrm{m}$, medulla cells ca. $8.5-10$ $(12) \times 12-14$, often single large cells $(15-17 \times 19-20)$ are mixed with relatively small $(10 \times 10-15 \mu \mathrm{m})$. Cells of stem surface isodiametric or slightly elongate, $15-20 \times 15-25 \mu \mathrm{m}$ with incrassate walls with distinct "Tangl's" canals (Fig. 1-4). Rhizoids infrequent on leafy shoots and quite numerous on flagella, arising singly from stem. Leaves ca. $200 \times 200-$ $215 \mu \mathrm{m}$ on well developed shoots to very small $(140 \times 140 \mu \mathrm{m}$ to scale-like in flagella), remote to more or less dense obliquely spreading or suberect, with dorsal half transversly or subtransversly inserted, concave or canaliculate, broadly ovate, bifid with more or less acute or obtuse sinus to 0.45-0.55 of leaf length; lobes subacute, 3-5 cells broad, ending by one or two superposed more or less isodiametric cells. Ventral merophytes 2-3 cells broad with deeply often unevenly bifid underleaves. Underleaves small, 30-50×65-70 $\mu \mathrm{m}$ to occasionally relatively large to half as large as leaf. Lobes of underleaves one or two cells wide, ending in slime papillae, sometimes with several slime papillae on margins. Cells of leaves small isodiametric, ca. $16 \mu \mathrm{m}$ on margin of lobes and 19-20(-24) in the middle. Walls of cells more or less thick with distinct "Tangl's" canals (look likes numerous transverse lines on walls, Figs. 1-13\&14). Asexual reproduction unknown.

Dioecious. Androecia on ventral-intercalary branches which often have several pairs of reduced sterile leaves prior to bract production or between pairs of bracts, spicate, of 3- 12 pairs of imbricate, concave, mostly 2 or sometimes 3 -lobed bracts. Antheridia 1 per bract with 2-seriate stalk. Perianth very large for the size of the plant, ca. $0.5-0.65 \mathrm{~mm}$ wide and to $1.6 \mathrm{~mm}$ long, trigonous with blunt to rounded angles, one-stratose, free from bracts and bracteole, mouth lobulate-ciliolate with cilia formed of (1-)2, rarely 3 superimposed elongate cells, uppermost cell usually $12-14 \mu \mathrm{m}$ wide at base and 30-34 $\mu \mathrm{m}$ long. Female bracts and bracteole slightly connate, similar in form and size, in two pairs and usually one subinvolucral pairs of leaves, much larger than leaves (to 0.35 $\mathrm{mm}$ wide and $0.7 \mathrm{~mm}$ length), bilobed ca. 0.5 0.85 of their length with acute sinus, margins of lobes with scattered one-celled teeth. Seta elongate with 8 epidermal and 4 inner cell rows, capsule wall 2-stratose (Fig1-24), epidermal cells with nodular thickenings of long or sometimes short walls, inner cells with semiannular bands, spores finely granulate-papillate, $8-10 \mu \mathrm{m}$, elaters 2 -spiral, ca. 5-6 $\mu \mathrm{m}$ wide, elater bands ca. $2 \mu \mathrm{m}$ wide.

Ecology. Very little is known about the ecology of Iwatsukia jishibae. Most published records of this species have only very general descriptions of the sites where it was collected. In the tropics, all specimens of $I$. jishibae are restricted to rotting wood at altitudes usually greater than $1800 \mathrm{~m}$. In Siberia, the species is strongly restricted to decaying logs in wet forests. In the Khamar-Daban Range, $I$. jishibae was collected at elevations of $500-700 \mathrm{~m}$ in valleys of the Pereyemnaya and Anosovka Rivers in Pinus sibirica-Vaccinium myrtillus- green moss forest and in Pinus sibirica-Abies sibirica-Picea obovata-herbs forests and in deep ravines with Populus suaveolens Fish., Pinus sibirica Du Tour and Abies sibirica Ledeb. Here, it was found always on the lower (near the soil) surface of large logs of Pinus sibirica and often formed thin mats covering square decimeters of wood. In the Udokan Range, the species was collected on decaying wood of Betula ermanii Cham., at $1100 \mathrm{~m}$ in Betula ermaniiRosa acicularis-Actea-Athyrium felix-femina forest. Here, there were only some plants of $I$. jishibae found as an admixture to Lophozia ventricosa (Dicks) Dumort. var. guttulata (Lindb. et Arnell) Bakalin. This locality is the northernmost locality for this species. In the Khamar-Daban Range hepatic species associated with $I$. jishibae are characteristic of decaying wood: Anastrophyllum michauxii (F.Weber) H. Buch, Mylia taylori (Hook.) Gray, Lepidozia reptans (L.) Dumort., Ptilidium pulcherrimum (Weber) Vain., Tritomaria exsecta (Schmidel ex Schrad.) Loeske and Bazzania bidentula (Steph.) Steph. And,. less often, Blepharostoma trichophyllum (L.) Dumort., Cephalozia macounii (Austin) Austin, Riccardia latifrons (Lindb.) Lindb. R. palmata (Hedw.) Carruth., Crossocalyx hellerianus (Nees ex Lindenb.) Meyl., and Lophozia ventricosa var. longiflora (Nees) Macoun.

Fig. 1. Iwatsukia jishibae (Steph.) Kitagawa (from Khamar-Daban Range, Konstantinova, 4-01, KPABG) 1-2: shoots; 3 - stem transverse section; 4 - stem surface; 5 - underleaf, right lobe ends with slipe papilla (SP); 6-8 leaves; 9 - basal lead cells; 10,12-13 - leaf cells near sinus (note "Tangl's" canals in 12-13); 11 - cells of lobe; 14-15 - male brackts; 16 - young perianth with bracts; 17 - subinvolucral leaf; $18-19$ - female bracts; 20 - part of perianth transverse section; 21 - perianth; 22-23 - perianth mouth; 24 - capsule wall transverse section; 25 epidermal cells of capsule wall; 26 - inner cells of capsule wall; 27 - spores; 28-29 - elateres. 

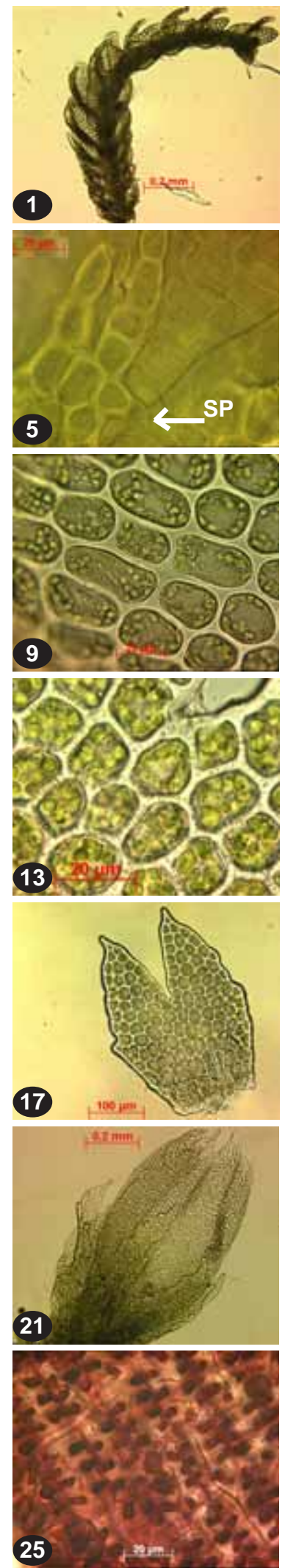
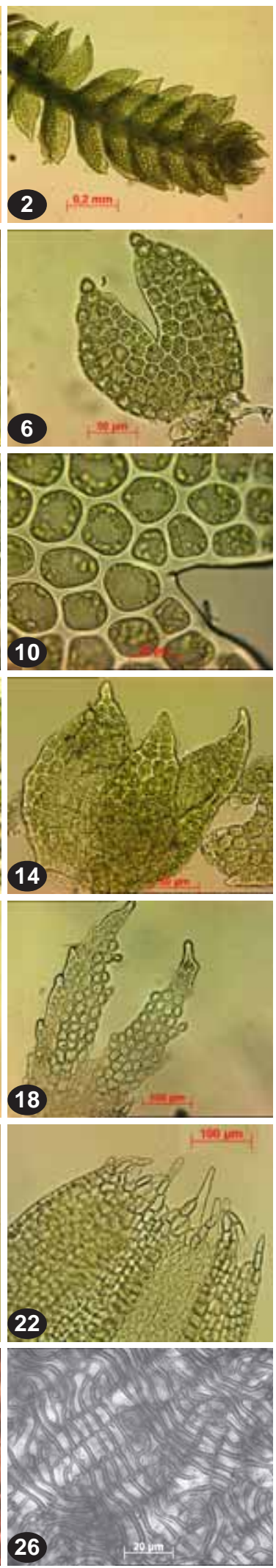
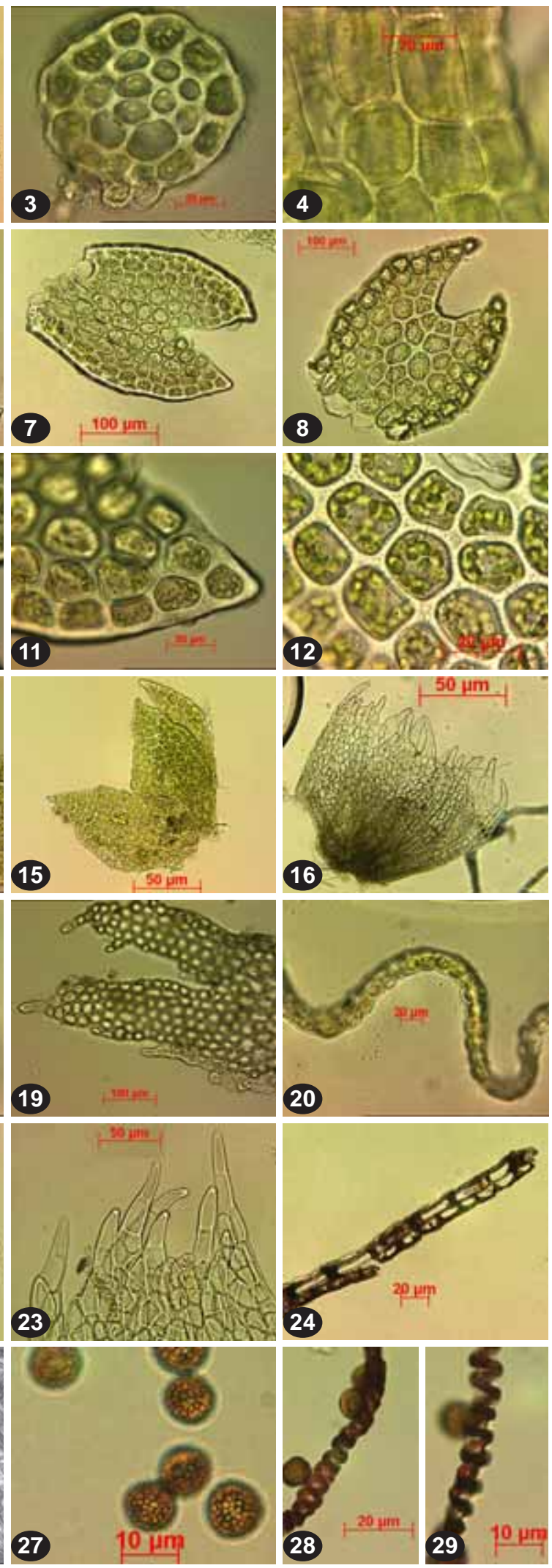


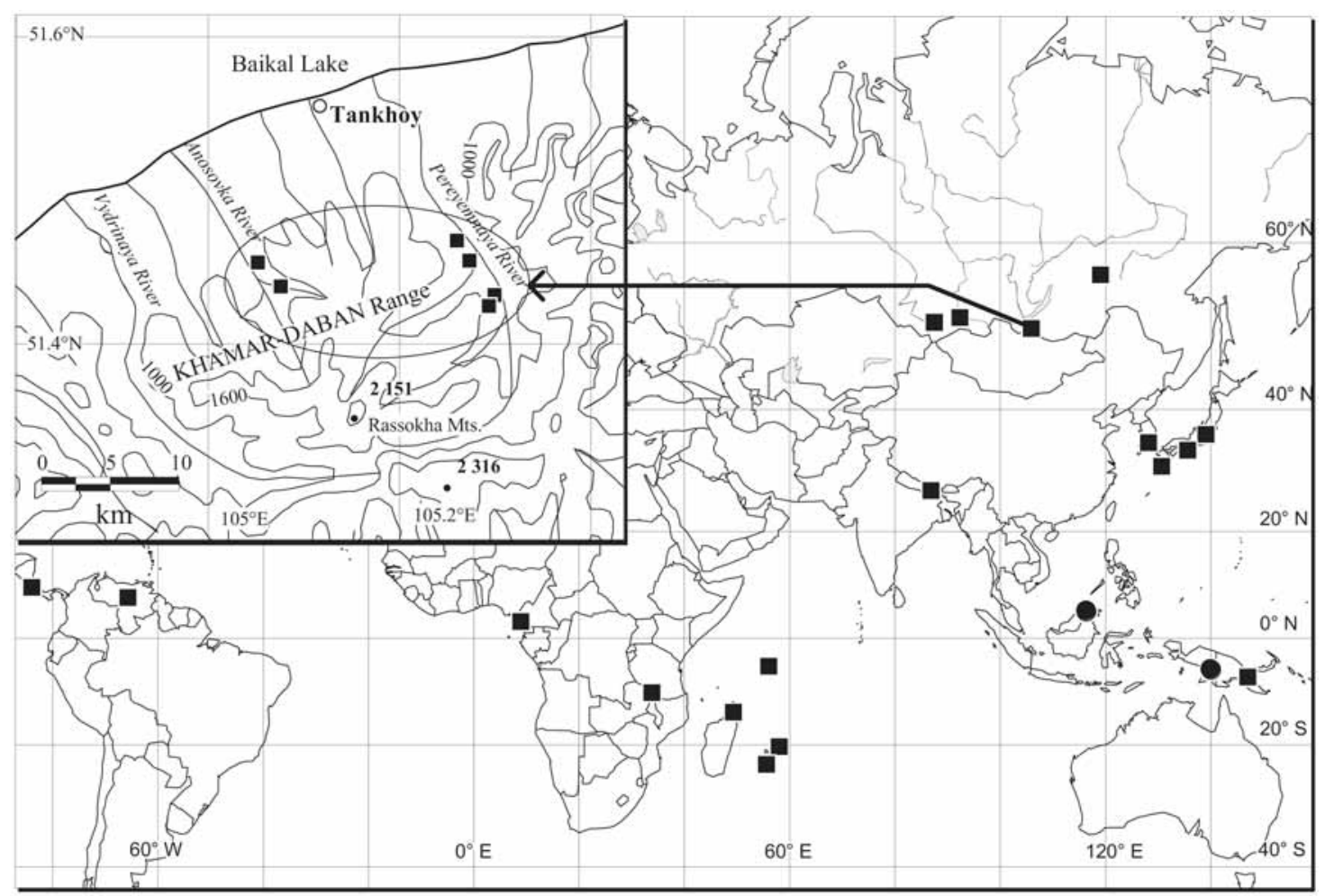

Fig. 2. Distribution of Iwatsukia jishibae (Steph.) Kitagawa (squares) and I. exigua Kitagawa (circles); expanded from Vana, 1991-1992.

Distribution. Iwatsukia jishibae is rare worldwide, highly disjunct, and mostly a subtropical-tropical species. Asia. Russia: South Siberia (Sayan, Altai, Khamar-Daban); south East Siberia (Udokan); Japan (Honshu, Kyushyu), South Korea (Hong, 1966), East Nepal (Grolle, 1965). Malesia: Papua-New Guinea (Vana \& Piippo,1989). Indian Ocean islands: Mauritius, Reunion (Grolle \& Onraedt, 1974), Seychelles (Grolle, 1978). Africa: Aequatorial Guinea and Malavi (Wigginton, 2004); Madagaskar (coll. Pocs \& al., H) (Fig.2). Central America: Costa Rica (Vana, 1980).

The herb-fern-fir-Pinus sibirica forests and poplar forests of the northern macroslope of the Khamar-Daban Range, as well as of some parts of the Sayan Mountains are characterized by the abundance of Tertiary relicts of vascular plants and lichens (Urbanavichus, 1997). Ecologically, these forests are very similar to the Tertiary mesophytic, broad-leaved and coniferous-broad-leaved forests. Thus, the discovery here of I. jishibae, a species with a predominantly tropical distribution, seems quite natural. It supports the idea that the northern macroslope of the Khamar-Daban Range, including the valleys of the Pereyemnaya and Anosovka Rivers, is a refuge for the Tertiary flora.

Specimens examined: Russia. South Siberia, Western Sayan, Sayanskiy Range, Ala-Yan River, on decaying wood, associated with Anastrophyllum michauxii, Lepidozia reptans A.N.Vasiljev, 27.VII.1987 (KPABG); Altai Mountains, the northern shore of Telezkoye Lake, Bolshoye Istyube Creek, $470 \mathrm{~m}$, on strongly rotten decorticated logs, Ignatov 22.07.1991(MHA, KPABG); Khamar-Daban Range, Pravaya Anosovka River, ca. 640 m, 16-1, 2a, 4-01, Konstantinova (KPABG); idem, valley of the Zheltyi Bereg River, 520 m, 39-01 Konstantinova (KPABG); idem, the middle reach of the Pereyemnaya River, ca. $700 \mathrm{~m}, 55-1-01$, Konstantinova (KPABG); idem, the valley of the Nemskiy Klyuch River, ca. 630 m, 96-1-01, Konstantinova (KPABG); idem, the middle reach of the Pereyemnaya River, ca. 580 m, 48-1, 2, 3a-01, 49-1, 2,3-01, Konstantinova (KPABG); East Siberia, Udokan Range, 15-26-00, Bakalin (KPABG).

Madagaskar, Antsiranana, 1220, corticolous. 28-31990, Pocs \& al., 90114 / CK (H3174738). Costa Rica, Cartago, 2700 m. Holz CR00-543 (H3202307). 


\section{DIFFERENTIATION}

Iwatsukia jishibae is distinctive in the field because of a combination of characteristic features: small size, light or pale-green color of plants, presence of characteristic rigid flagellae, conduplicate leaves. The more characteristic microscopic features that differentiate it from all species of Cephaloziaceae are markedly equally thick-walled cells with many distinct "Tangl's canals". In the minute size, more or less transversely inserted and conduplicate leaves, often small but distinctly bilobed underleaves, $I$. jishibae is superficially similar to some Cephaloziella spp. Cephaloziella spp. differ, however, in: 1) usual presence of secondary pigmentation: 2) lacking characteristic flagellae; 3 ) stem anatomy (medullary cells of $I$. jishibae are much longer than cortical); 4 ). presence often of gemmae; 5). walls of cells may be thick, but never have "Tangl's canals"; 6). seta anatomy (in Cephaloziella seta usually $4+4$ type vs. 8+4 type in Iwatsukia). The concaveconduplicate, suberect and subtransverse leaves, shape of the underleaves and slime papillae on them, and frequent flagellae, I. jishibae is similar to Cladopodiella francisci (Hook.) H. Buch ex Joerg. The latter species, however, is usually a little bit larger with stems $100-150 \mu \mathrm{m}$ (vs. $90 \mu \mathrm{m}$ in $I$. jishibae); leaves are more shallowly divided, the lobes of leaves are broadly or narrowly rounded or subacute, rarely acute; cortical cells are much longer (28-50); and secondary pigmentation (reddish to dark red or purplish red), as well as often abandoned gemmae are present. The ecology of these species is quite different. Cladopodiella francisci is a pioneer species on moist or wet, but well drained, acid, peaty soil, fine earth and sand. It never was collected on decaying wood, whereas $I$. jishibae is obligately epixilous, growing on logs in wet forests. From Cephalozia spp. that are often growing on decaying wood, I. jishibae differs in: 1) very thick cell walls with "Tangl's canals"; 2) copious characteristic flagella production; 3) absence of a hyalodermis; 4) much smaller cortical cells; 5) conduplicate, mostly suberect or erect spreading leaves.

\section{KEY TO GENERA OF CEPHALOZIACEAE IN RUSSIA}

1. Leaves unlobed, cells usually collenchymatous, often with coarse trigones; oil-bodies large, 25 per cell, filling lumen . . . Odontoschisma

- Leves more or less deeply bifid, cells lacking distinct collenchyma; oil-bodies small or absent .......... . . 2
2. Underleaves large, mostly bilobed, similar to leaves in shape and size; median cells of leaves clearly elongated (often ca. 1.5-2 times as long as wide); gametangia on leading leafy stem; capsule with epidermal cells sub-isodiametric, all walls with nodular trigones; hydrophytes occurring on wet cliffs and rocks along streams, often at least partly submerged . . . . Hygrobiella

- Underleaves distinctly different from leaves in shape and size or absent; median cells of leaves usually isodiametric or slightly elongate (less than 1.5 as long as wide); gametangia on short, postical, abbreviated ventral-intercalary branches . . . . . 3

3. Underleaves always present, quite large (usually much more than half of leaf length), unlobed, ovate-lanceolate or lanceolate, bracteoles smaller than bracts, often unlobed; branches mostly lateral-terminal, rarely lateralintercalary; cell walls pigment free; capsule with epidermal cells elongate, their transverse walls lacking thickenings; arctic-alpine species of places with late snow . . Pleurocladula

- Underleaves much smaller than leaves (often less than half of leaf length), usually bifid or absent, bracteoles more or less identical to bracts in size and form; [what about branches, cell walls, capsule, habitat?] . . . 4

4. Leaves concave with characteristic inflated base and decurved ciliate lobe apices formed of more than 5 superimposed cells; epixylous, usually on moist decaying logs, very rare on peat soil or cliffs . . . . Nowellia

- Leaf base not inflated and leaf lobes acute, terminated by 1-3 superimposed cells, or obtuse; [what about habitat?] . . . 5

5. Plants relatively large, 1-3 mm wide; stem rigid, soft textured, elliptical, 0.6-0.9 mm wide; gemmae spherical to ovoid, mostly 2celled; leaves sometimes 2-stratose at base; plants light green without secondary pigmentation; underleaves variable, from very small and bifid to relatively large (up to one third of leaf length) or sometimes absent; flagellae absent. Arctomontane species occurring on wet slopes and along streams in alpine and subalpine belt (recently found in Far East of Russia by Bakalin, 2005) ........ Schofieldia 
- Plants smaller, sterile shoots usually not more than $1.5 \mathrm{~mm}$ wide; stem not rigid, less than $0.3(-0.4) \mathrm{mm}$ wide; gemmae one-celled or if two-celled then triangular to irregularly angular or almost stellate . . . 6

6. Underleaves absent on vegetative axes (very rarely large Pleurocladula-like underleaves sporadically exist in Cephalozia bicuspidata s. lat.); stem mostly with distinct hyalodermis (apart from C. pachycaulis and some forms of C. pleniceps); gemmae 1-celled, antical leaf-free zone usually evident, often more than 1-celled, flagellae very rare in gemmi parous shoots . . Cephalozia

- Underleaves small, but distinct, with slime papillae regularly presented, 2-lobed; stem without hyalodermis; leaves inserted to the antical midline; gemmae (in Cladopodiella francisci) 2-celled or absent; flagellae often present . . . . . . . . 7

7. Plants minute (not more than $0.6 \mathrm{~mm}$ wide), pale or light green without trace of secondary pigmentation; leaves more or less canaliculate, with acute lobes, divided to the half the leaf length; leaf cells with equally thick walls with characteristic "Tangl's canals". Restricted to moist decaying logs ........... Iwatsukia

- Plants small to medium size $(0.5-2 \mathrm{~mm}$ wide), green with brownish, purplish or carmine secondary pigmentation; leaves flat or distinctly concave, never canaliculate, shallowly divided with the rounded lobes; leaf cells slightly to distinctly equally thickwalled without "Tangl's canals". Restricted to acidic constantly moist peaty or sandy soil and to peat bogs, hygrophytes or hydrophytes ...... Cladopodiella

\section{DISCUSSION}

The genus Iwatsukia was described by Kitagawa basing on the single species, I. exigua Kitagawa from Borneo (Kitagawa, 1964). Very soon, Kitagawa (1965) and Grolle (1965) realized that Cephalozia jishibae, described in 1924 from Japan by Stephani, should be referred to Iwatsukia. Later, Schuster (1968) has shown that neotropic genus Cladomastigum Fulford is a synonym of Iraksukia. Taxonomy of the genus was discussed in detail in Schuster $(1968,2002)$ who placed it in
Cephaloziaceae subfam. Alobielloideae R.M.Schust. According Schuster (2002), Iwatsukia includes four species: two mostly Old World, I. exigua, I. jishibae, and two Neotropical, I. spinosa (Fulf.) R.M.Schust. I. bifida (Fulf.) R.M.Schust. Schuster (2000) reported that the two Old World species differ mainly in 1) the size of underleaves (relatively large in I. exigua and minute in $I$. jishibae), 2) length-width ratio of female bracts (in $I$. exigua female bracts twice as long as wide and in I. jishibae length-width ratio ca. 1.5); 3) denticulation of perianth mouth (lobulate-ciliate in I. exigua and lobulate-dentate in I. jishibae). Additionally, Schuster reported that I. exigua has more dense leaves.

Structural features of the Siberian plants of Iwatsukia jishibae, suggest that the distinction between I. exigua and I. jishibae, as described by Schuster (2002) is not warranted. The plants in some Siberian specimens have relatively remote leaves, but many shoots in some specimens have quite dense leaves. The same is true in connection with the underleaves; they may be very small or sometimes relatively large with lobes up to 10 cells in length. Female bracts in the Khamar-Daban plants are often 1.7-2 times as long as wide, but subinvolucral leaves are wider. The perianth mouth in Siberian plants has cilia of two (rare three), distinctly elongate, superimposed cells (see description) that are quite similar to those illustrated in Kitagawa's description of I. exigua (Kitagawa,1964), with the only difference that three-celled cilia are prevalent in his illustration. Unfortunately, I did not examine specimens of $I$. exigua, but comparison of specimens of $I$. jishibae with descriptions and pictures of I. exigua suggest, at least provisionally, these species are conspecific.

\section{ACKNOWLEDGEMENTS}

I would like to thank A.N.Savchenko for preparing the map for publication, M. Ignatov and J.Vana for critical reading of manuscript, Diana Horton for correcting English, the administration of the Baikalskii State Nature Reserve and, especially, G. Urbanavichus for their great assistance in organizing the field trip in Khamar-Daban. This research was supported by the Russian Foundation for Basic Research, grant 03-04-49304. 


\section{LITERATURE CITED}

[BAKALIN, V. А.] БАКАЛИН, В. А. 2004. Печеночники Станового Нагорья (Восточная Сибирью). - [Hераtics of Stanovoe Nagor'e (East Siberia)] Arctoa 13: 73-83.

[BAKALIN, V. А.] БАКАЛИН, В. А. 2005. Schofieldia monticola Godfrey и Cryptocoleopsis imbricata Amakawa - новые роды печеночников (Hepaticae) для флоры России. - [Schofieldia monticola Godfrey и Cryptocoleopsis imbricata Amakawa - new genera of Hepatics in Russia] Бот. журн. [Bot. Zhurn.] 90 (4) (in press)

GROLLE, R. 1965. Miscellanea hepaticologica 31-40. - J. Hattori Bot. Lab. 28: 101-106.

GROLLE, R. 1978. Die Lebermoose der Seychellen. - Wiss. Zeitschr. Friedrich-Schiller Univ. Jena, Math.-Nat. R.27: 7-17.

GROLLE, R. \& M. ONRAEDTH. 1974. Lebermoose aus Madagaskar und den Maskarenen (1). - Lindbergia 2 230-233.

HONG, W. S. 1966. The leafy Hepaticae of South Korea and their phytogeographic relationships. Especially to the flora of North America. - Bryologist 69: 393-426.

KITAGAWA, N. 1964. A new genus of Hepaticae from North Borneo. - J. Hatt. Bot. Lab. 27: 178-182.

KITAGAWA, N. 1965. Cephaloziellaceae of Japan. - Acta Phytotax. Geobot. 21: 107-116.
KONSTANTINOVA, N. A. \& A. N. VASILJEV 1994. On the hepatic flora of the Sayan Mountains (South Siberia). - Arctoa 3: 123-132.

SCHUSTER, R.M. 1968. Studies on Hepaticae. XLV. On Iwatsukia Kitagawa. - Bull. Nat. Sci. Mus.11(3): 309-317.

SCHUSTER, R.M. 2002. Austral Hepaticae Part II. - Nova Hedwigia, Beiheft 119: 1-606.

[URBANAVICHUS, G. Р.] УРБАНВИЧЮС, Г. П. 1997. Неморальные реликты в лихенофлоре Байкальского заповедника. - [Nemorose relicts in the flora of lichens of the Baikal Reserve] Бот. журн. [Bot. Zhurn.] 82 (10): 88-99.

VANA, J. 1980. Some New South and Central American Hepatics. - J. Hattori Bot. Lab. 48: 225-234.

VANA, J. 1991-1992. Phytogeographically important hepatics from the Altai Mts. (Russia). - Novit. Bot. Univ. Carol. 7: 27-32.

VANA, J. \& S. PIIPPO 1989. Bryophyte flora of the Huon Peninsula, Papua New Guinea. XXXI. Cephaloziaceae subfam. Alobielloideae, Cephaloziellaceae, Antheliaceae and Lophoziaceae (Hepaticae). - Ann. Bot. Fennici 26: 263-290.

WIGGINTON, M.J. 2004. E.W.Jones's Liverwort and Hornwort of West Africa.- Scripta Botanica Belgica 30: $443 \mathrm{pp}$. 